\title{
РОЗВИТОК ТВОРЧИХ ЗДІБНОСТЕЙ УЧНІВ ЗАСОБАМИ РІДНОГО СЛОВА В ПОЗАУРОЧНИЙ ЧАС
}

\author{
Тетяна Бондаренко \\ кандидат педагогічних наук, доцент
}

ДВНЗ «Донбаський державний педагогічний університет»

м. Слов’янськ Донецької області, Україна

tetbond1960@gmail.com

Людмила Бутова

філолог, учитель вищої кваліфікаційної категорії

Миколаївського закладу загальної середньої освіти

I-III ступенів № 3

м. Миколаївка Донецької області, Україна

lbutova963@gmail.com

Валентина Вобленко

філолог, учитель вищої кваліфікаційної категорії

Миколаївського закладу загальної середньої освіти

I-III ступенів № 3

м. Миколаївка Донецької області, Україна

mmo2017@ukr.net

Анотація. Стаття присвячена проблемі розвитку творчих здібностей учнів засобами рідного слова в позаурочний час в умовах перезавантаження сучасної школи, що спричинило необхідність оновлення процесу методичної роботи вчителів-філологів. Автори розглянули змішане навчання як технологію забезпечення зазначеного процесу та запропонували шляхи вдосконалення розвитку творчих здібностей учнів засобами рідного слова в позаурочний час. 3'ясовано, що використання в процесі методичної роботи змішаного навчання активізує професійну діяльність учителів, розвиває здатність фахівців до самоосвіти.

Ключові слова: змішане навчання («Blended Learning»); методична робота; модель «Ротація за станціями» («Rotation Model»); педагогічна майстерня; професійна діяльність; творчі здібності.

Постановка проблеми в загальному вигляді. Інтеграційні процеси на шляху до європейського та світового освітнього простору актуалізували реформаційні зміни, які передбачають оновлення цілей та основних завдань загальної середньої освіти відповідно до сучасної парадигми і світових тенденцій розвитку освітніх систем.

Цільові та ціннісні трансформації сучасної освіти вимагають вирішення низки проблем, зокрема проблеми формування готовності до інновацій усіх учасників навчально-виховного процесу, створення умов для розвитку й самореалізації особистості, пошуку ефективних шляхів удосконалення професійної майстерності фахівців, спроможних до перезавантаження впродовж усього періоду педагогічної діяльності. 
У зв'язку з цим, особливу увагу необхідно звернути на залучення інноваційних форм організації методичної роботи вчителів щодо розвитку творчих здібностей учнів.

Аналіз останніх досліджень і публікацій показав, що творчість являє собою системне явище, що включає творчі здібності; творчий процес; якості особистості, які забезпечують творчу діяльність (В. Дружиніна, В. Моляко, Я. Пономарьова, В. Семиченко, С. Сисоєва та ін.). Деякі аспекти проблеми розвитку творчих здібностей учнів знайшли відображення в працях науковців, які розглядали потенціал розвитку творчої особистості (Л. Орбан-Лембрик), розвиток творчих здібностей учнів початкових класів як основи креативної особистості (В. Антипець, М. Артюх), основні чинники формування творчої особистості та розвитку ii творчих здібностей у процесі навчання (С. Сафарян) тощо. На сьогодні немає однозначного визначення поняття «творчих здібностей» та єдиного підходу до їхнього структурування. Проте більшість науковців сутністю творчих здібностей уважають здатність породжувати нові, оригінальні ідеї, ефективно вирішуючи проблемні ситуації.

О. Протас зазначає, що творчі здібності розглядаються дослідниками як індивідуально-психологічні здібності людини, що відповідають вимогам творчої діяльності та є умовою іiі успішного виконання, і пов'язуються зі створенням нового, оригінального продукту, із пошуком нових засобів діяльності [3]. С. Сафарян підкреслює, що проблема розвитку творчих здібностей, активізації творчої діяльності набуває пріоритетного значення. Учений відмічає, що вирішення цього важливого завдання покладено насамперед на систему освіти й потребує принципово нових підходів до навчання, виховання та підготовки до самостійного життя юного покоління, постійного оновлення форм і методів навчання для їхнього ефективнішого впливу на розвиток особистості учнів [4].

Сучасний стан реалізації творчих здібностей учнів у школі обумовлює нагальну потребу творчих, нестандартно-мислячих, креативних учителів, здатних до засвоєння та впровадження інновацій не лише на уроці, а й у позаурочній діяльності. У теорії та практиці вдосконалення професійної майстерності вчителів $\epsilon$ низка нерозв'язаних питань, зокрема в оновленні процесу методичної роботи щодо розвитку творчих здібностей учнів. Оновлення процесу методичної роботи надає широкі можливості для розвитку методичної компетентності, яка відображає спроможність учителів ефективн здійснювати освітньо-виховну діяльність, творчо реалізувати набутий теоретичний i практичний досвід залучати ефективні технології навчання, виховання й розвитку, що свідчить про їхню здатність до неперервного професійного й особистісного самовдосконалення.

Оскільки наші професійні інтереси здебільшого пов'язані з філологічною освітою, зосередимось на аспекті вдосконалення методичної компетентності вчителів-філологів, їхньої професійної майстерності щодо розвитку творчих здібностей учнів засобами рідного слова в позаурочний час. 
Результати аналізу опрацьованих теоретичних і методичних джерел із зазначеної проблеми дають підстави стверджувати, що методична компетентність учителя-філолога в галузі засобів формування знань, умінь i установок включає засвоєння нових методичних і педагогічних ідей, підходів до навчально-виховного процесу в сучасних особистісно зорієнтованих, розвивальних, креативних технологіях, володіння різними методами і формами організації навчання (активні, інтерактивні, методи кооперативного навчання, методи роботи 3 невстигаючими та обдарованими учнями, методи стимулювання творчо діяльності учнів різного віку, компетентнісно зорієнтований i диференційований, комунікативно-діяльнісний, соціокультурний підходи тощо) [5].

Ми поділяємо думку Л. Черчатої та схиляємося до розуміння методичної компетентності вчителя-філолога як складного інтегративного утворення, що становить поєднання результату методичної підготовки, тобто синтез знань (психолого-педагогічних, загальнонавчальних, предметних), умінь (загальнопедагогічних, спеціальних, комунікативних) і навичок педагогічної діяльності, необхідних для ефективної реалізації процесу навчання мови або літератури, методичного досвіду, отриманого в процесі професійної діяльності та особистісних рис педагога [6, с. 7].

Аналіз результатів роботи методичного об'єднання вчителів-філологів Миколаївського закладу загальної середньої освіти I-III ступенів №3 щодо вдосконалення методичної компетентності засвідчує, що підгрунтям є саме педагогічний досвід, який набувається як у процесі активної педагогічної діяльності, так і в ході самонавчання та самовдосконалення особистості. На нашу думку, розвитку творчих здібностей, формуванню творчо мислячої особистості ефективно сприяє змішане навчання («Blended Learning»), зокрема модель «Ротація за станціями» («Rotation Model»).

Формулювання цілей статті. Метою статті $\epsilon$ розглянути форми вдосконалення методичної компетентності, готовності вчителів-філологів до розвитку творчих здібностей учнів засобами рідного слова в позаурочний час.

Виклад основного матеріалу дослідження. Поширення інноваційних процесів у сучасному українському освітньому просторі передбачає пошук i впровадження ефективних технологій у процес удосконалення професійної майстерності, зокрема оновлення методичної роботи вчителів-філологів у вдосконаленні їхньої методичної компетентності, забезпеченні готовності до розвитку творчих здібностей учнів засобами рідного слова в позаурочний час.

За нашим переконанням, в умовах реалізації Концепції Нової української школи однією з ефективних форм забезпечення готовності вчителів-філологів до розвитку творчих здібностей учнів засобами рідного слова в позаурочний час $\epsilon$ майстерня. Саме така форма дає можливість зміщення акцентів зі знаннєвого на діяльнісний освітній результат і може бути застосована в діяльності як учнів, так і вчителів, ураховуючи специфіку, життєвий досвід, вікові особливості учасників. 
Цінність майстерень полягає в тому, що в процесі їхньої роботи акцентується увага на діяльності кожної особистості й створюються можливості для усвідомлення кожним учасником сутності цієї діяльності: майстерня незвичайне заняття, у ній відбувається «проживання» проблем, пошуку шляхів їхнього вирішення. Ми поділяємо думку I. Мухіної й уважаємо, що саме в майстерні досягається максимальне наближення до реального досвіду істинно наукового або художнього розуміння світу, тому що кожний ії учасник рухається від усвідомлення особистого досвіду до досвіду національної й загальнолюдської культури у вільній діяльності.

Зміст майстерень передбачає неперервну зміну творчих видів діяльності відповідно до мети поставлених завдань та охоплює систему творчих вправ, тренінгів, творчих завдань, розробку й презентацію проектів. Парна або групова взаємодія, активність і самостійність учасників, актуальний досвід й особисте переживання в процесі пошуку розв'язання певної проблеми вимагають використання сучасних освітніх технологій [2, с. 8].

На нашу думку, саме «Blended Learning», основною метою якого $\epsilon$ об'єднання переваг традиційного та дистанційного навчання, надає широкі можливості в забезпеченні найважливіших умов діяльності педагогічної майстерні. «Rotation Model», яка грунтується на принципі ротації, створює сприятливі умови навчання в групах згідно 3 певним графіком. Фахівці здобувають нові знання, переміщуючись від однієї станції до іншої, і крім того, на одній із станцій обов'язково $є$ он-лайн навчання, а іншими можуть бути навчання в групах, проектна робота, індивідуальні заняття з тренером, письмові завдання.

Особливості використання «Blended Learning», зокрема «Rotation Model» розглянемо в межах підготовки і проведення методичної майстерні «Розвиток творчих здібностей учнів засобами рідного слова в позаурочний час».

Проектуючи методичну майстерню, ми мали можливість забезпечити поступовість процесу, який складається з трьох основних етапів:

- с створення сприятливих умов до розгортання методичної діяльності, а саме: залучення вчителів до проведення заходу в методичний простір, який умотивовує їх до розв'язання проблем, що стають для них особистісно значущими;

- забезпечення суб'єкт-суб'єктних відносин у процесі роботи методичної майстерні, що створює особливу атмосферу, яка сприяє виникненню бажання до співпраці, продуктивної рефлексивно-оцінної діяльності на позитивний результат з урахування потреб кожного учасника (темп навчання, складність і обсяг матеріалів, формат взаємодії тощо);

- забезпечення зворотного зв’язку («Feed Back») після проведення майстерні.

На першому етапі було узагальнено досвід роботи вчителів-філологів із запропонованої теми; визначено станції, модераторів і форми роботи на них; 
створено путівник-дорадник, який містив усю інформацію, необхідну для комфортної та ефективної роботи методичної майстерні, а саме: коротко про технологію змішаного навчання «Blended Learning» і модель «Ротація за станціями» («Rotation Model»); регламент роботи: подорож станціями «Теоретична», «Етнографічна», «Народознавча», «Практична», «Традиційна»; додаткова інформація в рубриці «Детальніше...»; поради щодо роботи $\epsilon$ примітками «Про це спитаю: ...WOW! (Вау! Здивовані) Цікаво! Я це зроблю!» для ефективної рефлексії та підведення підсумків роботи методичної майстерні.

На другому етапі, подорожуючи станцією «Теоретична», В. Вобленко (філолог, учитель вищої кваліфікаційної категорії), прагнула створити умови для розкриття й реалізації творчого потенціалу кожного учасника майстерні, спираючись на презентацію результатів роботи творчої групи майстерні та професійний досвід колег, залучаючи їх до конструктивного діалогу, який дозволив у ході роботи набути нові знання та висловити судження стосовно власного досвіду із зазначеної теми.

На станції «Етнографічна» Л. Бутова (філолог, учитель вищої кваліфікаційної категорії) познайомила 3 учасниками проекту «Вишиванка генетичний код України». Учасники методичної майстерні мали можливість познайомитися зі специфікою організації позаурочної діяльності з української мови та літератури, яка дає реальну можливість учням виявити свої здібності, сприяє естетичному вихованню. Саме робота зі словом розвиває мислення, допитливість, спостережливість, творчу активність дитини.

Теоретичні «вкраплення» та вдале поєднання 3 практичною діяльністю в роботі методичної майстерні дозволило:

- $\quad$ побачити перспективу особистісного професійного розвитку;

- $\quad$ опановувати сучасні підходи до проектування творчого розвитку всіх учасників навчально-виховного процесу, пошуку способів вирішення проблемних ситуацій;

- $\quad$ поєднати різні види діяльності, різноманітні форми і методи роботи (від колективних до індивідуальних), що передбачає інтеграцію теоретичного та практичного навчання (професійно-педагогічної, психологічної, методичної, фахової готовності), засвоєння інноваційної діяльності;

- $\quad$ створити атмосферу взаємоповаги та доброзичливості, а як наслідок - здатність до активного педагогічного спілкування, взаємодії та відповідальності;

- створити умови для рефлексії та корекції діяльності: самоаналіз почуттів, емоцій, ставлення до оточуючих, аналіз «побоювань і надбань»у процесі роботи майстерні.

На станціях «Народознавча», «Практична» учасники методичного заходу мали можливість відчути, що методична майстерня стала формою активної співпраці, в основі якої - творча взаємодія вчителів-філологів і учнів. Спочатку в кімнаті-музеї (станція «Народознавча») філолог, учитель першої кваліфікаційної категорії Л.А.Бас разом 3 учнями презентувала форми 
краєзнавчої роботи, зокрема творчу діяльність гуртка «Сднаймось в гроно калинове». Учасники методичної майстерні мали можливість впевнитись яку визначну роль відіграє кімната-музей у процесі розвитку творчих здібностей учнів засобами рідного слова в позаурочний час, відчути, як передають красу рідного слова учні (Г. Волна, І. Бруханський) в процесі читання уривків 3 творів українських письменників.

На станції «Практична» познайомилися з результатами інноваційних форм розвитку творчих здібностей учнів засобами рідного слова в позаурочний час. Ініціативна група учнів «MEDIANNA» презентувала виступ на кінофестивалі «ДИТЯТКО», під час якого саме майстерне володіння рідним словом дало можливість повернутися переможцями сценарного пітчингу. Зйомки юними кіношниками майстер-класу «Інтерв'ю» в реальному часі дозволили вчителямфілологам «пережити», «пропустити через себе» процес опанування різноманітними інноваційними формами розвитку творчих здібностей учнів засобами рідного слова в позаурочний час, що взаємозбагатило всіх учасників майстерні та сприяло формуванню нового професійного досвіду. Саме станція «Традиційна» стала узагальненим етапом, який передбачав уточнення векторів творчої діяльності, інтерактивні вправи «Кути» («Займи позицію»).

Усі активності в межах роботи методичної майстерні грунтуються на партнерських засадах, суб’єкт-суб'єктній взаємодії всіх учасників. Завдання модератора - створити умови для розкриття й реалізації творчого потенціалу кожного учасника майстерні; розробити й реалізувати методику діалогу, який дозволяє набути необхідні знання та висловити власне судження; організувати індивідуальну й колективну роботу учасників майстерні, яка орієнтує їх на самостійну діяльність із побудови нових знань, створення «творчого продукту», яким стало «Інтерв'ю». Методична майстерня передбачає співтворчість досвідчених учителів і вчителів-початківців, має системний характер.

Висновки $з$ дослідження та перспективи подальших розвідок у цьому напрямі. Використання «Blended Learning», зокрема «Rotation Model» у процесі вдосконалення методичної компетентності вчителів-філологів, оновлення методичної роботи, доцільно дібрана технологія й форми навчання, творча особистість учителя-філолога, що здатна до неперервного професійного й особистісного самовдосконалення, зокрема в розвитку творчих здібностей учнів засобами рідного слова в позаурочний час, безперечно, є тими важливими чинниками, які сприяють формуванню і розвитку творчих здібностей учнів, підготовці їх до самостійної творчої професійної діяльності.

На нашу думку, перспективним напрямом подальших досліджень $є$ забезпечення організаційно-методичного супроводу діяльності методичної майстерні із метою вдосконалення методичної компетентності, готовності вчителів-філологів до розвитку творчих здібностей учнів засобами рідного слова в позаурочний час. 
Розвиток творчих здібностей учнів засобами рідного слова в позаурочний час

\section{СПИСОК ВИКОРИСТАНИХ ДЖЕРЕЛ}

1. Антипець, В. П. і Артюх, М. С. (2015). Розвиток творчих здібностей учнів початкових класів як основи креативної особистості. Вісник Чернігівського національного педагогічного університету. Серія : Педагогічні науки, Вип. 125, 279 - 282. - Режим доступу: http://nbuv.gov.ua/UJRN/VchdpuP_2015_125_68.

2. Кузьменчук, I. Технології педагогічної майстерні у підготовці вчителя до педагогічного проектування [Електронний ресурс]. - Режим доступу: http://svitlitkyiv.blogspot.com/p/blog-page_4192.html

3. Протас, О.Л. (2014). Розвиток творчих здібностей учнів в умовах загальноосвітнього навчального закладу. Освіта та розвиток обдарованої особистості, № 3, 26 - 29. - Режим доступу: http://nbuv.gov.ua/UJRN/Otros_2014_3_7

4. Сафарян, С. І. Основні чинники формування творчої особистості та розвитку їі творчих здібностей у процесі навчання. - [Електронний ресурс]. - Режим доступу: https://www.narodnaosvita.kiev.ua/Narodna_osvita/vupysku/1/statti/2safaryan/2safaryan.htm

5. Сидоренко, В. В. (2011). Модель професійної компетентності вчителя української мови і літератури в контексті впровадження компетентнісно зорієнтованого підходу. Наукова скарбниця освіти Донеччини: наук.-метод. журнал, № 1 (8), 72 - 77.

6. Сімоненко, Л. Ю. (2013). Методична компетентність як складник професійної компетентності вчителя української мови. Науковий вісник Донбасу, № 2. - Режим доступу : http://nbuv.gov.ua/j-pdf/nvd_2013_2_28.pdf.

7. Черчата, Л. М. (2015). Методична компетентність майбутнього вчителяфілолога: аспекти формування. Витоки педагогічної майстерності : зб. наук. пр. Полтавського нац. пед. університету ім. В. Г. Короленка / Полтавський нац. пед. ун-т ім. В. Г. Короленка. Полтава : ACMI, Вип. 16 (16), 292-299. - Режим доступу: https://docplayer.net/73127210Metodichna-kompetentnist-maybutnogo-vchitelya-filologa-aspekti-formuvannya.html

8. Шевченко О. Педагогічна майстерня як форма професійного розвитку молодого вчителя [Електронний ресурс]. - Режим доступу: http://www.stattionline.org.ua/pedagog/106/19101-pedagogichna-majsternya-yak-formaprofesijnogo-rozvitku-molodogo-vchitelya.html

\section{РАЗВИТИЕ ТВОРЧЕСКИХ СПОСОБНОСТЕЙ УЧАЩИХСЯ СРЕДСТВАМИ РОДНОГО СЛОВА ВО ВНЕУРОЧНОЕ ВРЕМЯ}

Татьяна Бондаренко

кандидат педагогических наук, доцент

ГВУЗ «Донбасский государственный педагогический университет»

г. Славянск Донецкой области, Украина

tetbond1960@gmail.com

Людмила Бутова

филолог, учитель высшей квалификационной категории

Николаевского заведения общего среднего образования

I-III ступеней № 3

г. Николаевка Донецкой области, Украина

lbutova963@gmail.com

Валентина Вобленко

филолог, учитель высшей квалификационной категории

Николаевского заведения общего среднего образования 


\title{
I-III ступеней № 3 \\ г. Николаевка Донецкой области, Украина \\ mmo2017@ukr.net
}

\begin{abstract}
Аннотация. Статья посвящена проблеме развития творческих способностей учащихся средствами родного слова во внеурочное время в условиях перезагрузки современной школы, повлекшее необходимость обновления процесса методической работы учителей-филологов. Авторы рассмотрели смешанное обучение как технологию обеспечения указанного процесса и предложили пути совершенствования развития творческих способностей учащихся средствами родного слова во внеурочное время. Установлено, что использование в процессе методической работы смешанного обучения активизирует профессиональной деятельности учителей, развивает способность специалистов к самообразованию.
\end{abstract}

Ключевье слова: смешанное обучение («Blended Learning»): методическая работа; модель «ротация по станциям» («Rotation Model»); педагогическая мастерская; профессиональная деятельность; творческие способности.

\section{DEVELOPMENT OF PUPILS' CREATIVE ABILITIES OF MEANS NATIVE WORD IN AFTER SCHOOL ACTIVITIES}

\author{
Tetiana Bondarenko \\ Candidate of Pedagogical Sciences, Associate Professor \\ SHEE "Donbas State Pedagogical University" \\ Sloviansk, Donetsk region, Ukraine \\ tetbond1960@gmail.com \\ Liudmyla Butova \\ philologist, teacher of the highest qualification category \\ Mykolaivka institution of general secondary education \\ I-III degrees № 3 \\ Mykolaivka, Donetsk region, Ukraine \\ lbutova963@gmail.com \\ Valentyna Voblenko \\ philologist, teacher of the highest qualification category \\ Mykolaivka institution of general secondary education \\ I-III degrees № 3 \\ Mykolaivka, Donetsk region, Ukraine \\ mmo2017@ukr.net
}

\begin{abstract}
The involvement of innovative forms of organizing methodological work of teachers on the development of students' creative abilities is acutely relevant because of target and value transformations of modern education. Analysis of recent research and publications showed that creativity is a systemic phenomenon, which includes: creative abilities; creative process; personal qualities that provide creative activity.

The authors argue that the methodological competence of a teacher-philologist in the field of means of knowledge, skills and attitudes formation includes the assimilation of new methodological and pedagogical ideas, approaches to the educational process in modern personally oriented, developing, creative technologies, possession of various methods and forms of training organization (active, interactive, methods of cooperative learning, methods of working with inexperienced and gifted students, methods of stimulating the creative activity of pupils of different ages, communicative
\end{abstract}


and activity, social and cultural approaches, etc.). The analysis of the results of the methodological association of teachers of philology concerning the improvement of methodological competence testifies that the pedagogical experience acquired both in the process of active pedagogical activity and in the course of self-study and self-improvement is the basis personality According to our belief in the development of creative abilities, the formation of a creative thinking person is effectively promoted by blended learning, in particular the rotation model. The purpose of the article is to consider forms of improvement of methodical competence, readiness of teachers-philologists to develop the creative abilities of students by means of the native word in extra-curricular time.

The authors described the design of a methodical workshop, which consisted of three main stages: the involvement of teachers before the event in the methodical space, which motivates them to solve problems; providing subject-subject relations in the process of methodical workshop; providing feedback after the workshop.

Key words: blended learning; methodological work; rotation model; pedagogical workshop; professional activity; creative abilities.

\section{REFERENCES (TRANSLATED AND TRANSLITERATED)}

1. Antypets, V. P. and Artyukh, M. S. (2015). Development of creative abilities of primary schoolchildren as the basis of a creative personality. Bulletin of Chernihiv National Pedagogical University. Series: Pedagogical Sciences, Vip. 125, 279-228. - Mode of access: http://nbuv.gov.ua/UJRN/VchdpuP_2015_125_68.

2. Kuzmenchuk, I. Technologies of pedagogical workshop in preparing teacher for pedagogical designing [Electronic resource]. - Access mode: http://svitlit-kyiv.blogspot.com/p/blogpage_4192.html

3. Protas, O. L. (2014). Development of creative abilities of students in a general educational institution. Education and development of gifted personality, № 3, 26 - 29. - Access mode: http://nbuv.gov.ua/UJRN/Otros_2014_3_7

4. Safaryan, S. I. The main factors of formation of a creative person and development of her creative abilities in the process of learning. - [Electronic resource]. - Mode of access: https://www.narodnaosvita.kiev.ua/Narodna_osvita/vupysku/1/statti/2safaryan/2safaryan.htm

5. Sidorenko, V. V. (2011). Model of professional competence of the teacher of the Ukrainian language and literature in the context of the introduction of a competently oriented approach. Scientific treasury of education in Donetsk: science-method. Magazine No. 1 (8), 72 - 77.

6. Simonenko, L. Yu. (2013). Methodical competence as a component of the professional competence of the teacher of the Ukrainian language. Scientific Bulletin Donbass, № 2. - Mode of access: http://nbuv.gov.ua/j-pdf/nvd_2013_2_28.pdf.

7. Church, L. M. (2015). Methodical competence of the future teacher-philologist: aspects of formation. Origins of pedagogical skill: Sb. sciences Ave Poltava Nats. ped university them V.G. Korolenko / Poltava Nats. ped Un-t them. V.G. Korolenko. - Poltava: ASMI, Vip. 16 (16), 292-299. - Access mode: https://docplayer.net/73127210-Metodichna-kompetentnist-maybutnogo-vchitelyafilologa-aspekti-formuvannya.html.

8. Shevchenko, O. Pedagogical workshop as a form of professional development of a young teacher [Electronic resource]. - Mode of access: http://www.stattionline.org.ua/pedagog/106/19101pedagogichna-majsternya-yak-forma-profesijnogo-rozvitku-molodogo-vchitelya.html

Матеріали надійшли до редакції 27.11.2018 р. 